\title{
Prevalence of Toxoplasma gondii Antibodies in Domestic (Columba livia domestica) and Wild (Columba livia livia) Pigeons in Niğde region, Turkey
}

\author{
Niğde Yöresinde Evcil (Columba livia domestica) ve Yabani Güvercinlerde
}

(Columba livia livia) Toxoplasma gondii Antikorlarının Prevalansı

\author{
Mustafa Karatepe ${ }^{1}$, Selçuk Kılıç², Bilge Karatepe1, Cahit Babür² \\ ${ }^{1}$ Niğde University, Bor Vocational School, Niğde, Turkey \\ ${ }^{2}$ Ministry of Health, Ankara Refik Saydam National Institute of Hygiene, Ankara, Turkey
}

\section{ABSTRACT}

Objective: The present study was conducted to investigate the prevalence of Toxoplasma gondii specific antibodies in domestic (Columba livia domestica) and wild (Columba livia livia) pigeons between October 2003-June 2004.

Methods: Blood samples were collected from 216 pigeons, consisting of 105 (55 female, 50 male) domestic pigeons and 111 (53 female, 58 male) wild pigeons. The sera were tested for T. gondii antibodies using the Sabin Feldman Dye Test (SFDT).

Results: One of the $105(0.95 \%)$ domestic pigeon and one of the $111(0.90 \%)$ wild pigeon were found to be seropositive for T. gondii antibodies at the titer of 1:16.

Conclusion: This is the first serological study on toxoplasmosis in the domestic and wild pigeon in the Niğde region of Turkey.

(Turkiye Parazitol Derg 2011; 35: 23-6)

Key Words: Columba livia domestica, Columba livia livia, pigeon, Toxoplasma gondii

Received: $09.10 .2010 \quad$ Accepted: 01.12.2010

\section{ÖZET}

Amaç: Bu çalışma, Niğde yöresinde evcil (Columba livia domestica) ve yabani (Columba livia livia) güvercinlerde Toxoplasma gondii'nin seroprevalansının saptanması amacı ile yapılmıştır.

Yöntemler: Bu amaçla Ekim 2003-Haziran 2004 tarihleri arasında Niğde yöresinden 105'i evcil (53 dişi, 58 erkek) toplam 216 güvercinden kan alınmış ve serumları çıkarılmıştır. Elde edilen serumlar T. gondii antikorları açısından Sabin-Feldman boya testi ile incelenmişlerdir.

Bulgular: Test sonucunda 105 evcil güvercinin 1'i (\%0.95) ve 111 yabani güvercinin 1'i (\%0.90) 1/16 T. gondii antikorları yönünden titrede seropozitif bulunmuştur.

Sonuç: Bu çalışma, Niğde ilinde evcil ve yabani güvercinlerdeki toxoplasmosis üzerine yapılan ilk serolojik çalışmadır.

(Turkiye Parazitol Derg 2011; 35: 23-6)

Anahtar Sözcükler: Columba livia domestica, Columba livia livia, güvercin, Toxoplasma gondii

Geliş Tarihi: 09.10.2010 Kabul Tarihi: 01.12.2010

\section{INTRODUCTION}

Toxoplasmosis, one of the most common parasitic infections in mammals and birds, is caused by Toxoplasma gondii. The definitive hosts are domestic cats, including wild felidae. Various warm-blooded animals serve as intermediate hosts (1). The ingestion of food or water contaminated with oocysts from cat faeces or the ingestion of tissue cysts in undercooked meat are the two major ways of postnatal transmission of T. gondii $(1,2)$.
Although symptoms such as diarrhea, trembling, incoordination, torticollis and severe encephalomyelitis may be observed in the acute period, T. gondii infections are often subclinical in pigeons (1,3-6). Therefore toxoplasmosis can be diagnosed by histological $(4,5,7-9)$ and immunohistochemical examination (9-11), necropsy findings $(3-5,12,13)$ and by use of bioassays in mice $(4,5,11,13,14)$. In addition, many serological tests such as Modified Agglutination Test (MAT), Latex Agglutination Test (LAT), Direct Aglutination Test (DAT), Indirect Hemagglutination (IHA), Enzyme Linked

This study is presented in XIV th National Congress of Parasitology (18-25 September 2005, Izmir, Turkey)

Address for Correspondence/Yazışma Adresi: Dr. Mustafa Karatepe, Niğde University, Bor Vocational School, Niğde, Turkey Phone: +90 3883114527 Fax: +90 3883118437 E-mail: mkaratepe@nigde.edu.tr doi:10.5152/tpd.2011.06 
Immunosorbent Assay (ELISA) and Sabin Felman Dye Test (SFDT) have been used to detect T. gondii antibodies (3-7, 12, 13, 15-19).

There are a few reports regarding toxoplasmosis in pigeons in Turkey. The first study on pigeon toxoplasmosis in Turkey was reported by Babür et al. (20). In this study, Babür et al. (20) did not find T. gondii antibodies in 60 pigeons in Ankara province, by using SFDT. Then, T. gondii seropositivity was obtained in $1.29 \%$ pigeons of the İzmir and Manisa province with SFDT (21).

The purpose of this study was to determine the prevalence of antibodies against T. gondii in domestic and wild pigeons in Niğde region, Turkey.

\section{MATERIALS AND METHODS}

Study area: This study was performed on domestic (Columba livia domestica) and wild (Columba livia livia) pigeons of the Niğde province, in the middle of Turkey (with an altitude of $1240 \mathrm{~m}, 37^{\circ} 58^{\prime} \mathrm{N}$ longitude-3441' E latitude), where toxoplasmosis was not previously recognized. Because it has a subtropical climate, the summers are warm and dry and the winters are cold and snowy. The annual average of precipitation is $348.8 \mathrm{~mm}$, average temperature is $11.1^{\circ} \mathrm{C}$ and average relative humidity is $55 \%$ in Niğde.

Sampling of pigeons and blood collection: This study was carried out between October 2003-June 2004, Niğde. During this period, wild pigeons were captured from roofs of buildings, and domestic pigeons were obtained from pigeon keepers and all pigeons brought alive to the laboratory in a bird cage.

A total of 216 pigeons which were more than one year old, were selected randomly as the study samples. Blood samples were obtained from these pigeons, which consisted of 105 (55 female, 50 male) domestic pigeons and 111 (53 female, 58 male) wild pigeons. The blood samples were collected from a punctured wing vein (vena cutenea ulnaris) in a sterile tube. Serum samples were obtained by centrifugation at room temperature $\left(25^{\circ} \mathrm{C}\right)$, at $4000 \mathrm{rpm}$ for 10 minutes and were stored at $-20^{\circ} \mathrm{C}$ until used.

Serologic examination: Serum samples were tested at the Ankara Refik Saydam National Institute of Hygiene (RSNIH), Department of Communicable Diseases Research for T. gondii antibodies with the Sabin Feldman Dye Test (SFDT) conducted as described (22). SFDT was modified by Feldman and Lamb (23) and serial double-fold dilutions were applied.
As a vigorous antigen, 48 hours passage of $T$. gondii Rh strain derived from the peritoneal fluid of 3-4 week aged white swiss albino mice were used. As an activator serum, seronegative for T. gondii and $\mathrm{Mg}^{2}$, properdin, $\mathrm{C}_{2} \mathrm{C}_{3^{\prime}} \mathrm{C}_{4}$ rich human serum was used. The sera were first inactivated in $56^{\circ} \mathrm{C}$ for 30 minutes, then four-fold serum dilutions from 1:4 to 1:1024 were prepared and stored in aliquots of $25 \mu$ in eppendorf tubes. The mixture of vital T.gondii tachyzoytes and activator serum were added to serum dilutions and incubated in a water-bath at $37^{\circ} \mathrm{C}$ for 50 minutes. Methylene-blue dye prepared with alkaline soda borax was added to each tube in equal amounts and kept in a water-bath at $37^{\circ} \mathrm{C}$ for 10 minutes.

The SFDT result was regarded as positive if more than $50 \%$ of tachyzoits did not accept the dye (unstained) at $\geq 1: 16$ examined under the light microscope (x 400).

\section{RESULTS}

A total of 105 serum samples from domestic pigeon and 111 serum samples from wild pigeon were examined for T. gondii. Antibodies to T. gondii were found in 1 (0.95\%) of 105 domestic pigeon and $1(0.90 \%)$ of 111 wild pigeon with a titer of $1: 16$. Both of the positive cases were male pigeons.

The distribution of SFDT titers are shown in Table 1.

\section{DISCUSSION}

Toxoplasmosis symptoms such as encephalomyelitis, ataxia, incoordination, trembling, torticollis, anorexia, diarrhea, pneumonia, iridocyclitis and blindness may be observed in naturally and experimentally infected pigeons, although in general, toxoplasmosis progresses subclinically in pigeons $(1,7,15)$.

Diagnosis of toxoplasmosis has been conducted by histological examination, necropsy findings, immunohistochemical, bioassays and serological methods in avian species $(1,15,24)$. Serodiagnosis of $T$. gondii infection in pigeons has used serological tests including MAT, LAT, DAT, IHA, ELISA and SFDT (3-7, 12, 13, 15, 17-19). Jacobs et al. (6) detected T. gondii antibodies in pigeons with Dye test in an experimental study. In the Biancifori et al study. (7), IgG response was investigated with ELISA in experimentally infected pigeon and all of the infected groups demonstrated seroconversion. In pigeons, Kirkpatrick et al. (17) found seroprevalence of $T$. gondii to be $5.9 \%$ by using MAT in the USA, Ghorbani et al. (25) detected the seroprevalence rate of T. gondii as $33.3 \%$ by using IHA in Iran, Mushi et al. (26) detected T. gondii specific antibodies as $100 \%$ by using IHA in South Africa, Waap et al. (19) found the T. gondii seroprevalence to be $4.6 \%$ by using

Table 1. Distribution of SFDT titers (T. gondii antibodies) in domestic (Columba livia domestica) and wild (Columba livia livia) pigeons

\begin{tabular}{|l|c|c|c|c|c|}
\hline Groups & $\begin{array}{c}\text { Number of } \\
\text { tested pigeons }\end{array}$ & $\begin{array}{c}\text { Number of } \\
\text { seropositive sera }\end{array}$ & $\begin{array}{c}\text { Seropositivity } \\
\text { (\%) }\end{array}$ & \multicolumn{2}{|c|}{ SFDT titer } \\
\hline Domestic pigeon & $\begin{array}{c}105 \\
\text { (55 female, } 50 \text { male) }\end{array}$ & 1 & 0.95 & $1 / 16$ & $1 / 64$ \\
\hline Wild pigeon & $\begin{array}{c}111 \\
\text { (53 female, } 58 \text { male) }\end{array}$ & 1 & 0.90 & 1 & 0 \\
\hline TOTAL & $\begin{array}{c}216 \\
\text { (108 female, } 108 \text { male) }\end{array}$ & 2 & 0.92 & 2 & 0 \\
\hline
\end{tabular}


DAT in Portugal and Salant et al. (18) detected anti-T. gondii antibodies as $4 \%$ by using MAT in Israel.

In Turkey, the epidemiology of toxoplasmosis has not been extensively investigated and little is known of the distribution and prevalence of the diseases in pigeons, because there are few reports regarding it. The first report on toxoplasmosis in pigeons from Ankara was studied by Babür et al. (20). In this survey (20), no anti-T. gondii antibodies were detected in all of the examined pigeons. Later, T. gondii seropositivity was obtained as $1.29 \%$ in pigeons of the Izmir and Manisa province with SFDT (21).

However, T. gondii prevalence was reported in domestic fowls (chicken, turkey, duck, geese, quail) and wildbirds (buzzard, falcon, owls, sparrow hawk, heron) as $0-12.50 \%$ in Turkey (27-31).

In our study, seroprevalence of T. gondii was found to be $0.95 \%$ in domestic pigeons and $0.90 \%$ in wild pigeons from Niğde in Turkey. The seroprevalence result of the present study was in accordance with the results obtained by the other studies $(20,21)$ performed on pigeons in Turkey. The prevalence of anti-T. gondii antibodies in pigeons has been reported from different countries. The general prevalence of toxoplasmosis in pigeons varies between $4-100 \%$ in various countries. The various prevalences of the disease may be associated with the geographical location and type of serological tests.

In conclusion, this study demonstrated that $T$. gondii seropositivity is low in domestic and wild pigeons in Niğde. In spite of low seropositivity, T. gondii infection in pigeons may be of epidemiologic importance because pigeons can serve as sources of tissue cysts for domestic and wild carnivores. The pigeons are herbivores and feed from the ground. Therefore, they become infected postnatally mainly by ingesting food or drink contaminated with oocysts shed in cat faeces. Pigeon meat can also serve as a source of organisms for hunters and their families when meat from these animals is consumed undercooked or uncooked. Therefore, more extensive studies are required to determine the seroprevalence rates in human and animals, and its implications for both animal and human health in the Niğde region, Turkey.

\section{Acknowledgements}

This article was submitted in the XIV. National Congress of Parasitology (18-25 September 2005, İzmir-Turkey) as a communique.

\section{Conflict of Interest}

No conflict of interest is declared by the authors.

\section{REFERENCES}

1. Dubey JP, Beattie CP. Toxoplasmosis of Animals and Man. CRC Press Inc Boca Raton, Florida. 1988.

2. Dubey JP. Advances in the life cycle of Toxoplasma gondii. Int J Parasitol 1998; 28: 1019-24. [CrossRef]

3. Dubey JP, Camargo ME, Ruff MD, Wilkins GC, Shen SK, Kwok OC, et al. Experimental toxoplasmosis in turkeys. J Parasitol 1993; 79: 949-52. [CrossRef]

4. Dubey JP, Goodwin MA, Ruff MD, Kwok OC, Shen SK, Wilkins GC, et al. Experimental toxoplasmosis in Japanese quail. J Vet Diagn Invest Thullienz P, 1994; 6: 216-21.
5. Dubey JP, Ruff MD, Wilkins GC, Shen SK, Kwok OC. Experimental toxoplasmosis in pheasants (Phasianus colchicus). J Wildl Dis 1994. 30: $40-5$.

6. Jacobs L, Melton ML, Cook M. Experimental toxoplasmosis in pigeons. Exp Parasitol 1953; 2: 403-16. [CrossRef]

7. Biancifiori F, Rondini C, Grelloni V, Frescura T. Avian Toxoplasmosis: Experimental infection of chicken and pigeon, Comp Immunol Microbiol Infect Dis 1986; 9: 337-46. [CrossRef]

8. Mikaelian I, Dubey JP, Martineau D. Severe hepatitis resulting from toxoplasmosis in a barred owl (Strix varia) from Quebec, Canada. Avian Disases 1997; 41: 738-40. [CrossRef]

9. Quist CF, Dubey JP, Luttrell MP, Davidson WR. Toxoplasmosis in wild turkeys: a case report and serologic survey. J Wildl Dis 1995; 31 : 255-8.

10. Mason RW, Hardley WJ, Dubey JP. Lethal toxoplasmosis in a little penguin (Eudyptula minor) from Tasmania, J Parasitol 1991; 77: 328 [CrossRef]

11. Vickers MC, Hartley WJ, Mason RW, Dubey JP, Schollam L. Blidness associated with toxoplasmosis in canaries. J Am Vet Med Assoc 1992; 200: 1723-5.

12. Dubey JP, Ruff MD, Kwok OC, Shen SK, Wilkins GC, Thullienz P Experimental toxoplasmosis in bobwhite quail (Colinus virginianus). J Parasitol 1993; 79: 935-49. [CrossRef]

13. Dubey JP, Ruff MD, Camargo ME, Shen SK, Wilkins GC, Kwok OC, et al. Serologic and parasitologic responses of domestic chickens after oral inoculation with Toxoplasma gondii oocysts. Am J Vet Res 1993; 54: $1668-72$.

14. Dubey JP, Karhemere S, Dahl E, Sreekumar C, Diabate A, Dabire $\mathrm{KR}$,et al. First biologic and genetic characterization of Toxoplasma gondii isolates from chickens from Africa (Democratic Republic of Congo, Mali, Burkina Faso and Kenya). J Parasitol 2005; 91: 69-72. [CrossRef]

15. Dubey JP. A review of toxoplasmosis in wild birds. Vet Parasitol 2002 106: 121-53. [CrossRef]

16. El-Massry A, Mahdy OA, El-Ghaysh A, Dubey JP. Prevalence of Toxoplasma gondii antibodies in sera of turkeys, chickens and ducks from Egypt. J Parasitol 2000; 86: 627-8. [CrossRef]

17. Kirkpatrick CE, Colvin BA, Dubey JP. Toxoplasma gondii antibodies in common barn-owls (Tyto alba) and pigeons (Columba livia) in New Jersey. Vet Parasitol 1990; 36: 177-80. [CrossRef]

18. Salant H, Landau DY, Baneth G. A cross-sectional survey of Toxoplasma gondii antibodies in Israeli pigeons, Vet Parasitol 2009; 165: 145-9. [CrossRef]

19. Waap H, Vilares A, Rebelo E, Gomes S, Angelo H. Epidemiological and genetic characterization of Toxoplasma gondii in urban pigeons from the area of Lisbon (Portugal), Vet Parasitol 2008; 157: 306-9. [CrossRef]

20. Babür C, Gııık Y, İnci A. Ankara'da güvercinlerde Sabin-Feldman boya testi ile anti-Toxoplasma gondii antikorlarının araştıııması. Türkiye Parazitol Derg 1998; 22: 308-10.

21. Babür C, Pişkin FC, Bıyıkoğlu G, Mutlu ÖF. İzmir ve Manisa yöresi güvercinlerinde (Columba sp.) anti-Toxoplasma gondii antikorlarının Sabin-Feldman boya testi ile araştırılması. Türkiye Parazitol Derg 1999; 23: 309-11.

22. Sabin $A B$, Feldman $H A$. Dyes as microchimical indicators of new immunity phenomenon affecting a protozoon parasite (Toxoplasma). Science 1948; 108: 660-3. [CrossRef]

23. Feldman HA, Lamb GA. A micro modification of the Toxoplasma Dye Test. J Parasitol 1966; 52: 415. [CrossRef]

24. Last RD, Shivaprasad HL. An outbreak of toxoplasmosis in aviary collection of Nicobar pigeons (Caloenas nicobaria). J S Afr Vet Assoc 2008; 79: 149-52.

25. Ghorbani M, Gharavi MJ, Kahnamoui A. Serological and parasitological investigations on Toxoplasma infection in domestic fowls in Iran. Iranian J Publ Health 1990; 19: 9-17. 
26. Mushi EZ, Binta MG, Chabo RG, Ndebele R, Panzırah R. Seroprevalence of Toxoplasma gondii and Chlamydia psittaci in domestic pigeon (Columba livia domestica) at Sebele, Gaborone, Botswana. Onderstepoort J Vet Res 2001; 68: 159-61.

27. Bıyıkoğlu G, Kılıç S, Babür C, Ayçiçek H. Marmara bölgesi damızlık işletmelerinde yetiştirilen tavuklarda anti-Toxoplasma gondii antikorlarının araştııılması. Türkiye Parazitol Derg 2002; 26: 355-7.

28. İnci A, Babür C, Dinçer Ş, Erdal E. Türkiye'nin bazı illerinde evcil kanatılarda Sabin-Feldman boya testi ile anti-Toxoplasma gondii antikorlarının saptanması. Türkiye Parazitol Derg 1998; 22: 420-3.
29. Inci A, Babür $C$, İşcan KM, İça A. Bıldırcınlarda (Coturnix coturnix japonica) Toxoplasma gondii (Nicole ve Manceaux, 1908) spesifik antikorlarının Sabin-Feldman boya testi ile araştırılması. Türkiye Parazitol Derg 2002; 26: 20-2.

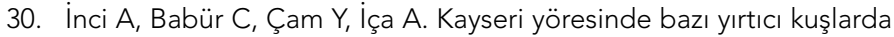
Sabin-Feldman boya testi Toxoplasma gondii (Nicole ve Manceaux, 1908) seropozitifliğinin araştırılması. F Ü Sağ Bil Derg 2002; 16: 177-9.

31. Zeybek H, Dündar B, Altıntaş K, Güngör C. Ankara yöresi tavuklarında Toxoplasma gondii'nin seroprevalansı. Etlik Vet Mikrobiyol Derg 1997; 9: 91-8. 